Volume 7, Issue 2, 407 - 419.

ISSN: 2165-8714

http://www.eu-jer.com/

\title{
Candidate Teacher Education Program Confusion in Turkey
}

\author{
Figen Cam Tosun * \\ Sinop University, TURKEY
}

\author{
Muzaffer Simsek \\ Bayburt Provincial Directorate of National Education, TURKEY
}

Received: March 3, 2018 - Revised: April 15, 2018 - Accepted: April 15, 2018

\begin{abstract}
In this research, the purpose is to investigate the practice of teacher candidate procedure and engage in a discourse on the teacher candidates' views on the practice. The qualitative method has been used in order to analyze teacher candidates' views on the subject. The subjects of the study comprise 57 teacher candidates currently working in Bayburt. Semi-structured interview forms consisting of questions about the way the teacher candidate education is implemented and questions that refer to their thoughts about the practice were used as data gathering instrument. In this research, content analysis technique has been used for the analysis of the data collected through the interviews. The codes reached through the answers from the informants and their frequencies have been given. The codes with high frequencies have been supported with excerpts from teacher candidates. As a result of the study, it has been found out that most of these teachers who were involved in teacher candidate training consider it 'a waste of time'. With flexibilities allowed and without proper planning, the practice of the procedure is found to have prevented achievement of the goal. Furthermore, the practice of contract adjunct teaching has also brought about some contradictions.
\end{abstract}

Keywords: Teacher candidate education, teacher candidate, teacher trainee procedures, initial teacher education.

To cite this article: Cam Tosun, F., \& Simsek, M. (2018). Candidate Teacher Education Program Confusion in Turkey. European Journal of Educational Research, 7(2), 407-419. doi: 10.12973/eu-jer.7.2.407

\section{Introduction}

Education is an important indicator reflecting a nation's development level. It also provides access to the items that enable the community to live in integrity. Therefore, one of the most important factors in demand is teachers. It is of paramount importance to note how teachers, who make a community become a whole, are educated.

Teacher training is a process which should start before undergraduate education, following student selection. Another most important stage following this is training qualified teachers in education faculties. This process should be designed comprehensively as we have seen in recent past. They need to be educated to become intellectuals for both the students they will guide and the society. Teachers, early in their careers, should be trained without retreating from science and modern education and, constantly, are expected to engage in in-service training programs in order to be able to follow current matters. After graduating, with the start of their careers, candidate teacher education starts, different examples of which we can see in various countries. Hoy and Woolfolk (1990) state that candidacy period is very significant especially in order for teachers to adapt to teaching as a profession. Balci (2000) and Lay and et al (2005) emphasize that this period underlies how teachers will feel toward their job in the years to come. If the process goes successfully, the feelings toward teaching will be positive. According to Korkmaz and et al (2004), no matter how successful teachers may be during their pre-service education period, they encounter real life when they start working. For this reason, they are thinking that teacher candidate period is an adaptation process for real life.

The necessity of the candidate teacher education, it is possible to encounter many works in many field writing. Also, it is possible to see this in different countries with a different practice. According to which priorities do these countries organize in the candidate teacher education? What is the priority in candidate teacher education? With this, some of the questions need to be answered.

1. Is it right to train by mentorship method?

2. Is the idea of being trained in school right?

3. How should the adaptation process to school be?

4. Is it necessary to take part in seminars for a specific time?

\footnotetext{
* Corresponding author:

Figen Cam Tosun, Sinop University, Faculty of Education, Department of Educational Sciences, Turkey

Email: figencam@gmail.com
} 
5. If the on-line training method is applied, what should be the concept?

6. Is examination necessary for finalizing candidacy status?

7. If the exam is applied, what should be measured?

8. Can teachers' performance be measurable? While each student and each school is different from others, can a standard performance be determined?

It is considered that, after the answers given to this and similar other questions, planning teacher candidate education leads the country to better achievements. Different applications have been conducted in teacher candidate training in Turkey, so far.

\section{Background}

After establishing the Turkey Republic, there have been given a weight of training teacher issue, in 1935 training instructor and rural teacher movement, and then opening Village Institutes reached the peek (1940), it became permanent solutions for training village teacher (Arkin 1945). In the year of 1954, by shutting down Village Institutes turned into Village School and with these changes, the purpose of training teacher was continued (Altunya, 1990). In the later years, Teacher High School, Teacher College and Educational Faculty that were developed the source of teacher training came until today by adding political effect and assigning teacher from the different background.

Within the realm of teacher education, the first study accepted on 10/06/1930 was "The Law about Primary and Middle School's Teacher's Promotions and Punishments" and it was published in the Official Gazette (issue 1532) on 29/06/1930. In the fourth article of this law it is observed that "It starts with the first mission as a trainee. At the end of the internship year, equipped with qualifications and the capacity of teaching, the trainee receives a title as "teacher" by a committee report and internship record. In the profession, seniority is calculated according to the date when the title is granted. It is not possible to be promoted unless the title of 'teacher' is obtained and the interns who cannot receive the title within two years are dismissed." In the examination of the records, the Law No. 4357 "Other Laws Related to Candidate Teacher Education," which was adopted on 13/01/1943, entitled "Promotion, Punishment and Punishment of the Primary School Teachers Receiving Salaries from Private Administrations and the Contribution of the Teachers to the Building Fund with Health and Homicide Assistance for Such Teachers" "appears in the second article. According to this article, "those newly appointed as primary school teachers to receive salaries from private administrations work as interns for a period ranging from one to three years. Whether they are successful in the internship will be determined by the Ministry of Education based on the authorization sent from the office of the governor or a three-person board formed under the presidency of the regional primary education inspector or the education officer. According to the type of school and the number of teachers the candidate teacher is appointed to, what is expected to be done are listed item by item (Arkin, 1945).

When we come to our recent history, in view of the Decree for Amendments to the Basic Law of National Education No. 6528 published in the Official Paper dated 14 March 2014 and numbered 28941 on the date of 01/03/2014, Article 27 of the Law on Amendments to Certain Laws and Decrees in the Law, and 4357 of the Law on the Civil Servants Law No. 657 enacted on 14/07/1965 because of the withdrawal of certain elements from the enforcement of the Law No. 4357, the third part of the Civil Servants Law No. 657 enacted on 14/07/1965, issues related with the candidates are applied according to the principles in the Articles 54 and 55. According to this situation, the prospective teacher candidate passes through three stages of education as basic, preparatory and practical, and in case they are successful, they are appointed to the cadre. Teacher appointment and nomination procedures started to be carried out according to the "Regulation on the Appointment and Placement of Teachers of the Ministry of National Education" published in the Official Paper dated April 17, 2015 and numbered 29329 in order to carry out the nomination procedures of the teachers after the 6528 numbered law passed in 2014. Based on items 15-26 of the regulation, "Candidate teachers shall be entitled to enter written and oral examinations to be conducted by the Ministry provided that they fulfill the conditions for success at least for one year and according to performance evaluation". Before arriving at this stage, candidate teachers are subjected to the training period for six months. Candidate teachers who are appointed as subject to this regulation are referred to as "Independent teaching and guard duty cannot be given during the training process for the candidate teachers" in Paragraph 3 of Article 5 of the Regulation on the Candidate Teacher Training Process, which was enacted with the approval of the Ministry Authorization dated 02/03/2016 and numbered 2456947. In this process, it is aimed that the candidate teacher should be trained only by the consultant teacher's listening and observing the lessons, and the supervisor should be observed during the guard duty, and the candidate teacher should be trained by the master teacher and other personnel in charge of training. It is aimed to gain professional experience by not only actively teaching for six months but also by entering the lectures besides the consultant teacher. At other times, it is desirable to study at least one or two of the recommended films, which are environmental examinations, at least five books to be read the recommended books. With this process, evaluators can participate in written and oral exams in case they have to take positive notes by evaluating one by the evaluator in the first period in which the relative is started and twice in the following period. The evaluators are; the provincial education supervisor, the supervisor of the educational institution where the candidate teacher is assigned, and the supervisor of the educational institution. Performance appraisal is applied to candidate teachers who actually work as teaching staff for at least two 
months in a period. Ministry candidates may be given framework training on the basis of professional criteria and written exam topics.

As the last step in candidacy training, employment of contracted teachers was legally accepted with the decree law 668 passed on 25.07,2016 and an amendment to the decree law 652 as regards the structure and mission of the Ministry of Education. Accordingly, those appointed as contracted teachers in accordance with Article 17 of the "Regulation on Contracted Teacher Employment" published in the OG dated 03/08/2016 and numbered 29790 are the Ministry of National Education published in the Official Gazette dated 17/4/2015 and numbered 29329. In accordance with the provisions of the Regulation on Teacher Appointment and Relocation Regulation, Ministry of Teacher Training and Development General Directorate, those assigned as teacher candidates will be subjected to candidacy training in accordance with the planning. And, according to Article 19 and as required in the contract, the first year is noted as training period. According to the Candidate Teacher Training Program dated 17/10/2016, a total of 642 hours of training will be provided, 384 hours for in-class and in-school activities, 90 hours for non-school activities and 168 hours for in-service training activities. During the first year, candidate teachers can attend classes independently. In addition, in-service training is required. Those who have succeeded in performance evaluation in the end of the first year and are assigned as contracted teacher candidates in the second, third and fourth years. However, these years do not receive training again. According to the performance score that only the schoolmaster will give, a new service contract is formed by the Directorates of National Education. Candidate teachers who have successfully completed these four years are appointed as permanent teachers in the fifth year. Teachers who complete the fifth and sixth years in the same area are granted the request for appointment.

To summarize these last two procedures, candidate teachers appointed between 2015 and October 2016 will have to be given performance evaluation three times in addition to the six-month training program, participate in standard written examinations and oral examinations by the committees to be established in the provinces. On written and oral examinations, the average score of at least 60 points is considered successful and those who score this and above can be assigned to the cadre. Contracted candidate teachers appointed after October 2016 are required to go through performance evaluation three times by attending the compliance seminar and in-service training program according to the program sent by the ministry in the first year. Successful candidates who are successful in these steps will be appointed to the cadre if they are successful in the second, third and fourth years of performance evaluations to be made each year.

On their research, Lynch, McCormack and Hennessy (2017) has revealed that different countries have different practices and some endeavors has been taken in order to develop candidate teacher education programs. There are some studies conducted by Thompson, Paek, Goe and Ponte (2005), Kane (2008), Ingersoll and Strong (2011), Mingo (2012) supporting that candidacy training programs in countries have positive outcomes.

The problem that this study focuses on consists of these: three different candidacy training programs, determining the positive and negative aspects of candidacy training under the supervision of supervising teacher, spotting differences in procedures while conversing with teacher candidates on the progress of the procedure and indecisive attitudes observed among candidates about the procedure.

In literature, it is seen that some studies in Turkey have focused on a single problem related to this topic. For example, in their study Kozikoglu and Cokuk (2017) studied the difference between where candidate teachers were appointed and where they completed their candidacy training program. There are also studies evaluating education according to the opinions of the candidate teachers. For instance, Gul, Turkmen and Aksel (2017) found out mostly positive results in their study. In their studies,_Kurum Yapicioglu, Ozturk and Yetim (2016), Oral and Demir (2016), Sarica and TuranOzpolat (2016), Ulubey (2017) seems to be more concerned with the development of candidate teachers and the curriculum.

\section{Aim of the Present Study}

This research aims to examine the implementation process of the candidate teacher practice in the schools and to describe the ideas of the candidate teachers about the practice. In this context, the following questions have been answered:

1. Which criteria do the prospective teachers choose according to the candidate teaching profession?

2. What are the views on how much schools prepare teacher candidates for the school they will be appointed to?

3. What do they think of the applicant teacher practice regarding the implementation process in schools?

4. What do they think about the adequacy of the supervising teacher assigned to them?

5. How are their relations with teachers and students in school? 


\section{Methodology}

\section{Model of the Research}

Qualitative research method was used to examine the application process of the candidate teacher practice in the schools and to describe the ideas of the candidate teachers about the application. Qualitative research is the use of qualitative data gathering methods such as observation, interview, and document analysis, and a qualitative process is being used in order to present perceptions and events in a natural and realistic manner (Yildirim \& Simsek, 2005). Qualitative research aims to understand and, as a result of the research process, define the reality as it occurs (Kumbetoglu, 2005). In the qualitative research method, interview forms were used to collect subjective evaluations of candidate teachers.

\section{Participants}

The subjects consisted of 57 individuals working as candidate teachers in Bayburt. When the subjects were chosen, purposeful sampling and convenient sampling methods were used. Purposive sampling allows for in-depth study of situations that are thought to be rich in information. From the purposeful sampling techniques provides speed and practicality for the research, allowing the researcher to choose a situation that is nearby and easy to access (Karasar, 2010). Personal data belonging to candidate teachers constituting the subjects are given in Table 1.

Table 1: Demographic characteristics of candidate teachers

\begin{tabular}{lll}
\hline Category & & $\mathrm{f}$ \\
\hline Gender & Female & 42 \\
Age & Male & 12 \\
& $20-25$ age & 35 \\
& $26-30$ age & 12 \\
Level & Primary School & 2 \\
& Middle School & 16 \\
\multirow{3}{*}{ Graduation Year } & High School & 13 \\
& 2009 & 1 \\
& 2011 & 1 \\
& 2012 & 5 \\
& 2013 & 9 \\
& 2014 & 15 \\
& 2015 & 21 \\
\hline
\end{tabular}

\section{Data Collection and Analysis}

Semi-structured interview forms were developed to examine the implementation process of the candidate teacher practice in the schools and to describe the ideas of the candidate teachers about the application. According to the recommendations of Buyukozturk (2005), the interview forms were prepared by the researchers. In order to reach the purpose of the research, there are eight candidate questions and eight open-ended questions, with candidate preferences, preference of the school, application process, the necessity of the application, admission of the advisor, and teacher and student relations. The validity of the interview forms was provided by the expert opinion. (four faculty members with PhD.) After receiving the expert opinions, the interview forms were finalized considering the criticisms and contributions. Additionally, pilot application was conducted. Semi-structured interview forms were given to candidate teachers directly. The answers of the candidate teachers were collected from the subjects.

In the analysis of the qualitative data obtained from the interviews, content analysis technique was used. The codes and frequencies are determined in the direction of the answers given by the candidate teachers to the questions. Intensive frequency domain codes were supported by the words of teacher candidates.

\section{Results}

Candidate teachers were first asked, "How do you rank the choices that are effective in your choice of school, where you are a candidate teacher, according to their importance?" Candidate teachers did not rank preferences that were important to them. The distribution of the first three options in this context is shown in Table 2. 
Table 2: Candidate teachers' reasons for choosing a candidate school

\begin{tabular}{|c|c|c|c|}
\hline Motive to Prefer & $\begin{array}{l}\text { Frequency of } \\
1 \text { st row } \\
\text { writers }\end{array}$ & $\begin{array}{l}\text { Frequency } \\
\text { of 2nd row } \\
\text { writers }\end{array}$ & $\begin{array}{l}\text { Frequency of 3rd } \\
\text { row writers }\end{array}$ \\
\hline For where my family lives & 43 & & \\
\hline For being near home & 3 & 23 & \\
\hline Because I went to university there & 3 & & 5 \\
\hline Because I know the School Administration & & 2 & 7 \\
\hline Because I know the possible supervising teacher & & 3 & 1 \\
\hline Because I think the managers will not make trouble & & 2 & 4 \\
\hline Other & \multicolumn{3}{|c|}{$\begin{array}{l}\text { Where I'm assigned, where someone from the } \\
\text { family works, where I complete my post graduate } \\
\text { degree, random }\end{array}$} \\
\hline
\end{tabular}

As seen in Table 2, the reason for their participation in the candidacy training in Bayburt is mainly due to their families living in Bayburt or being close to their home country. In the third place, it was the statement that I recognized the most repeated school administration. In the elections of the teacher candidates, the school, the management and the definition of the city are important factors.

The second question asked to the prospective teachers is in their thinking about how much the conditions of the school prepare them for the school they are assigned to. The codes and frequencies prepared according to the answers of the candidates are given in Table 3.

Table 3: Opinions of the candidate teachers about the preparation of the school's conditions

\begin{tabular}{lc}
\hline Codes & $\mathrm{f}$ \\
\hline The conditions are not equal & 23 \\
Not Preparing & 21 \\
The school assigned with the internship is in the same standard, so it is good & 14 \\
It is useful to do an internship at a better school & 8 \\
There are grades or school differences & 8 \\
Difference gives more experience & 4 \\
Satisfactorily prepared me & 2 \\
\hline
\end{tabular}

As seen in Table 3, most of the teacher candidates think that the conditions, though in different forms, are not equal and that they are not well prepared. Only two teachers stated that they were prepared satisfactorily. One of the teacher candidates summarized her thoughts as follows:

"I was assigned to the village school. I worked at a central and crowded school. I do not think we are well prepared because we are not on equal terms. This application should be done where we are." Candidate 1

Another noteworthy application is that candidates' schools have been established regardless of the branches and stages of the prospective teachers. Candidate 31 stated this with the following words:

"I was assigned to the elementary school, internship in a secondary school. I think that my gains are at a minimum." Candidate 31

57 The teacher stated that he only received 14 candidates from the candidate's school or at a school on the same criteria. They also think they are well prepared. One of the candidates says:

"I think that the school where I did my training and where I was appointed to be the same school and this was a great advantage in terms of knowing manager-teacher-student relationships." Candidate 14

Training and study programs were prepared for the training process of the M.E.B (Ministry of National Education) Regarding the Prospective Teacher Training Process. In general, the training program appears to be planned as three days of in-class activities, one day of school activities and one day of extra-curricular activities. The flexibility of the study program is provided by the expression 'the program will be prepared with respect to institutions and consultants'. In all the schools, the prospective teachers were asked how the process works in order to see if the program is being watched. The codes and frequencies prepared according to the answers of the candidates are given in Table 4. 
Table 4: Opinions of candidate teachers about how the practice works

\begin{tabular}{lr}
\hline Codes & $\mathrm{f}$ \\
\hline Listening for 3 days lesson- narration & 32 \\
1-day administrative work, form filling & 27 \\
4 days in school 1 day in ME Directorate & 2 \\
3 hours practice 3 hours planning & 2 \\
First 6 weeks observation & 11 \\
Participating in school activities & 14 \\
Done in accordance with regulations & 8 \\
I did not engage in anything outside responsibilities & 4 \\
School procedures & 4 \\
\hline
\end{tabular}

As seen in Table 4, not all teacher candidates were exposed to the same application. Different practices are observed in various schools. But generally, it is understood that after that candidates are observed first and then are allowed to teach. Variations in the details performed outside observation, administrative work or during non-teaching were observed. One of the candidates explained what was done in the process in the school with the following words:

"I entered empty classes. I entered the student absences on the day of the administration. I was an invigilator on the tests. I did observations (advisor teacher). I taught the subject on my own." Candidate 48

Some teacher candidates expressed their dissatisfaction with the work done in the process as one of the teacher candidates said:

"It was negative. We were seen by the students and other teachers as a means of filling in unattended courses, not as teachers. In-school observation is now responsible for the chores in the school (such as folding graduation robe)." Candidate 50

More than half of the prospective teachers (27) stated that they were bored of doing administrative work and completing the form. Candidate 40's words reveal this disturbance:

"It was not a useful process. I was continuously filling out reports. Due to the fact that the process is new, there has been considerable distress in uncertainties. I did not do anything that was not my job in the regulation but I cannot say that I did the teaching profession." Candidate 40

The frequency chart of the responses to the questions asked whether it is necessary for the candidates to perform the candidacy training in this way is given in Table 5.

\begin{tabular}{lc}
\multicolumn{2}{c}{ Table 5: Opinions of candidate teachers about the need for practice } \\
\hline Codes & $\mathrm{f}$ \\
\hline Necessary & 19 \\
Unnecessary & 26 \\
Both necessary and unnecessary & 11 \\
Total & 56 \\
\hline
\end{tabular}

More than half of the teacher candidates (26) see unnecessary while 19 candidates see it as necessary. It seems that most of the uninvited candidates are candidates who think that they are not preparatory, the school where they practiced candidacy and the schools they are assigned to are not of the same standard and who did not think much of the school where they receive candidacy training. Those who considered it necessary appear to be candidates who say that they do not have problems in their schools, that the schools are to the same standard, or that the school does not cause problems for them.

The frequency chart drawn up in the direction of the expressions used by the candidate teachers when explaining the reasons for seeing this training as unnecessary or unnecessary is given in Table 6.

Table 6: Opinions of candidate teachers about the reasons for the need for practice

\begin{tabular}{lc}
\hline Codes & $\mathrm{f}$ \\
\hline It allows self-improvement & 16 \\
Becomes accustomed to the appointed arrow & 3 \\
Unnecessary form filling & 11 \\
There are unnecessary applications & 7 \\
It is unnecessary because it is common to use different reading & 5 \\
Time lost & 6 \\
Exposure to negative views of students and teachers & 7 \\
The same internship in university & 11 \\
Advisor's suitability & 5 \\
\hline
\end{tabular}


As you can see from the charts, some of the candidates say that they have a chance to improve themselves and that is why it is a necessary practice; the majority of candidates see it as an unnecessary application for reasons such as unnecessary form filling, failures in school relations, and waste of time. Some candidates have described the following considerations:

"The candidate teaching process is an application that has positive sides as well as negative sides. While the advisor has made positive contributions to the benefit of our teachers, it has created adverse effects in terms of the students' acceptance of us and the way other teachers see us as well as the forms we had to fill in."

"I do not think it's necessary. It is very boring to listen to the supervisor's lessons ... I think it is pointless for us to waste time in this way while many teaching positions are filled in by Business Administration and Economics graduates. The process could have been useful, but we need to make some changes." Candidate 16

"I think it's an unnecessary process. A process that shakes the self-confidence of the teacher and victimizes the teacher. Supervising teachers would have at least ten years of experience, but in practice, they did not. This caused insufficient and selfish people to become supervisors. It is questionable how competent the supervising teacher is and in comparison with my competence." Candidate 48

They were expected to compare the training, they received with their undergraduate education or practice teaching which they performed as part of their pedagogical formation. The frequencies of the codes obtained from the words of the teacher candidates are given in Table 7.

\begin{tabular}{lc} 
Table 7: Opinions of candidate teachers toward comparison of candidacy training - school practice course \\
\hline Codes & $\mathrm{f}$ \\
\hline No difference & 19 \\
Salary / staff & 7 \\
Candidate teacher's responsibility is more & 22 \\
Candidate teachers teach longer lessons & 19 \\
School practice is inadequate & 9 \\
The school sees you as a teacher while you are a candidate & 3 \\
We see ourselves as a teacher when we are candidate teacher & 3 \\
\hline
\end{tabular}

As can be seen in Table 7, the highest frequency suggests that the responsibility of the candidate teacher is greater. There is no difference in the high rate that follows him, and the candidate teaches more during candidacy. According to the statements of the candidate teachers, the school application has the same effect if done more regularly and intensively. The views of the candidate teachers are given below:

"Similar features. Each has lectures, monitoring, and reports. The only difference is that the candidate teacher gets paid. For this reason, the license application period should be made more active and the candidacy period should be abolished. Pity for the state's money, on the one hand a teacher getting paid and, on the other, a pacified teacher getting paid (a candidate teacher)." Candidate 43

"I do not think that the implementation in the process I'm taking is very effective. Because it was just a day and I taught once. I was not nested with the students. I did not know the school exactly in all respects. During the candidate teaching process, I was in school every day, teaching and experiencing for three days a week, and I had the chance to communicate with the students." Candidate 5

Candidate teachers were asked their opinions on the evaluation of their performance by the advising teacher. The codes and frequencies generated in response to the replies are given in Table 8.

\begin{tabular}{lc} 
Table 8: Opinions of the candidate teachers regarding the evaluation of their performance by the advisor \\
\hline Codes & $\mathrm{f}$ \\
\hline He made a fairly good assessment & 27 \\
He was experienced & 20 \\
It was not sufficient & 13 \\
He was very qualified & 9 \\
It was sufficient & 6 \\
His 3-4 years of teaching was not sufficient & 5 \\
I see myself as more qualified & 4 \\
\hline
\end{tabular}

More than half of the candidate teachers said that the teacher made a fair assessment. According to the information obtained from the Directorate of National Education, the average of the scores given by the advisor teachers to the candidate teachers is $86-100$ points. Candidates with very high scores found the evaluation to be quite fair. Candidate 33 explained their views with these words. 
"I have tried to finish this process with positive contributions as much as possible, thanks to the support and guidance provided to me by my advisor, who is much more equipped than I am in terms of experience and knowledge. During the evaluation at the end of this process, the opinions of my advisor about me and the score he gave me made me quite happy." Candidate 33

While the criterion mentioned the most by candidates was "the advisor was experienced", other criteria such as sufficiency and being well-equipped was mentioned comparably less often. The number of candidates who found the advisor insufficient was also fairly high. In addition, five teachers stated that the advising teacher has been in the profession for about 3-4 years. This does not contradict the Directive on the Candidate Teacher Training Process. It is also not one of the prioritized criteria for selecting advising teachers. It does not seem to make sense for the conditions to be pushed or challenged further as every candidate was given the chance to take the evaluation wherever they please as long as it is available there. Opinions of candidates support this claim:

"I do not think that my counselor is helpful, because he/she has been serving only for a very limited amount of time." Candidate 18

"It is clear that the system is made up of just a formality or it is simply unnecessary because of the fact that I was given an advisor who had been in the profession for only four years, due to lack of advisors. (I am grateful for not having been commissioned out of the city, though...)" Candidate 44

Candidates were asked about their relationship with the advisor and other teachers in the school. The codes and frequencies generated in response to the replies given are below in Table 9.

\begin{tabular}{lc} 
Table 9: Opinions of candidate teachers about their relationship with advising teachers and other teachers \\
\hline Codes & $\mathrm{f}$ \\
\hline I had no problems & 18 \\
Both were friendly, helpful & 19 \\
The advising teacher was fine & 13 \\
The advising teacher was problematic & 3 \\
Other teachers did not see us as genuine teachers & 25 \\
Other teachers were problematic & 3 \\
\hline
\end{tabular}

The most frequently recurring situation judged by the candidates' answers is that they were discriminated by other teachers and that the teachers in the school did not see the candidates as genuine teachers. This has led to feelings of reluctance and loss of affection towards the profession. Candidate 47's response to this question is as follows:

"Our communication with our advisor was very good. We were able to chat about the process quite freely. I did not have any problems with the school principal either. But throughout the semester, we were ridiculed and mocked by the other teachers in the school. We were told that we did not deserve the salary we were being paid, and that we sat idle, doing nothing useful." Candidate 47

Only a third of the teachers stated that they did not have any problems, or that they could establish a proper relationship with the advisor and other teachers. One of the lucky candidates, Candidate 42 gave the following statement:

"The number of teachers in the school was very limited and they had a very sincere relationship. Most of them were originally from that city. They extended this relationship to me as well..." Candidate 42

Codes and frequencies of the replies given by the candidates to questions regarding their relationships with students and perspectives of students towards the candidates are given in Table 10.

Table 10: Opinions of candidate teachers about student relations

\begin{tabular}{ll}
\hline Codes & $\mathrm{f}$ \\
\hline I was perceived as a trainee teacher (teacher candidate attending internship during school) & 36 \\
They did not understand what we were there for, it was confusing & 10 \\
At the end of the process we were accepted as teachers & 9 \\
We built good relationships & 9 \\
It was not good & 4 \\
We were treated just like the other teachers were & 8 \\
We were seen like brothers and sisters & 4 \\
\hline
\end{tabular}

As can be seen in Table 10, the majority of the candidates stated that the students perceived them as trainees. This made it difficult for them to establish effective communications. One of the candidates summarizes the situation with these words:

"I do not think the students have fully adopted us. The students see us as intern teachers." Candidate 9 
Candidates receiving candidate assessment particularly in secondary education were found to be struggling a lot more, considering the ages and developmental periods of their students. Moreover, lecturing under the supervision of an advisor made it difficult for the candidates to communicate effectively and has caused confusion among younger students. Candidate opinions on this are as follows:

"I could not have my students to adopt me properly. I attended the classes together with the advisor, so they assumed I was a student as well. I did not feel like a teacher myself. I was unable to control the class. I could not express myself comfortably because we were constantly under supervision." Candidate 6

"The students did not understand what we were there for, at first. Sometimes they thought we were interns, even if we told them that we were candidates, it did not amount to much meaning for them. During the lesson, they did perceive us as teachers. But in some lessons, it was confusing for them because I attended with my advisor. But the students were always respectful ..." Candidate 34

Candidate teachers were finally asked their opinions on not being able to attend classes, receive responsibilities of classes/courses before their candidacy has been completed, the fact that substitute teachers can attend their classes without supervision and that they can receive class/course responsibility. The generated codes and their frequencies are given in Table 11.

Table 11: Opinions of the candidate teachers about the differences between the candidate teacher and the substitute teacher

\begin{tabular}{ll}
\hline Codes & $\mathrm{f}$ \\
\hline Substitute teacher has more freedom in lessons & 23 \\
Substitute teacher is easier for students to perceive as a teacher & 14 \\
Substitute person feels more like a teacher & 9 \\
Substitute teachers embrace school more & 8 \\
Lesson responsibility for the substitute teacher is more & 6 \\
Substitute teacher receives a smaller salary & 10 \\
Candidate teaching is more secure as a job & 6 \\
\hline
\end{tabular}

As seen in Table 11, candidates think those substitute teachers are more accepted as teachers, which reflects on their work and self-esteem. They see the only disadvantages of being a substitute teacher is the low-wage and the temporary work. Some of the candidates' explanations are as follows:

"Substitute teacher just concentrates on teaching, he has his own lesson schedule. We listen to lectures for 6 weeks, give lectures for 10 weeks but only for 3 hours. The candidate teacher does not have anything of his own in the school, so neither the other teachers nor the students adopt the candidate teacher." Candidate 40

"Both of them spend the same amount of effort. I know this, as I used to be a substitute teacher. There is no difference in terms of labor and performance, but the fees are obviously different. I do not approve of this practice. The need for more teachers should be met by appointing more teachers instead of insulting our hard work by hiring substitutes." Candidate 37

Some of the candidates criticize the practice with the following words:

"Before I was appointed, I also did substitute teaching. I do not think the candidate teaching process contributed anything positive to me. What I learned about teaching was learned when I was working as a substitute. The candidate teaching process was, for me, nothing but an idle semester with no actual work done." Candidate 47

"The system which cannot entrust the students to appointed teachers, the system which places already-appointed teachers under more 'education', somehow manages to entrust the students to substitutes! I am not saying that the substitutes are bad, they may even be more qualified than I am in some cases but the burden of having substitute teachers in this country will never come to an end..." Candidate 44

\section{Discussion and Conclusion}

Qualitative research methodology has been used in this research, which aims to examine the implementation of candidate teaching process in schools and to describe the thoughts of candidate teachers about the practice. Candidate teachers have been given the opportunity to do their candidacy training at the school they want. In this context, the first finding in the research has been the factors that candidate teachers have been paying attention to when choosing schools. When choosing schools, candidate teachers were seen too often pay attention to do it where their families reside or at least somewhere relatively close to their families. Choosing the place where their families live, brings the prospect of personally knowing school principals and possible advising teachers. Especially in small cities, it is inevitable that this situation will lead to a departure from professionalism. Teachers who live away from their families, friends, and acquaintances in the research conducted by Duran, Sezgin and Coban (2011) stated that they are very 
distant from their home where they are currently working and it is still a major problem that the difficulties of getting to and from home, that they miss their families and friends so much in the first week of their candidacy that they cannot focus on the class or the school and also that they feel very lonely. Teachers have expressed that over time they make new friends and these problems are overcome with adaptation to the environment. Looking at this research data, it seems that it is an appropriate decision to grant the right to receive the candidacy training, required by the Ministry of National Education, in the city they want. But will not the candidate teachers survive the same adjustment process when they go to the city or the school they were assigned to at the end of the term? Findings of the study of Kozikoglu and Cokuk (2017) supports this study.

Candidate teachers think that the school they receive education and the school they are appointed to do not have the same conditions and therefore they are not preparative. Some candidate teachers seem to have moved away from the purpose of education when they are considered to be receiving an education regardless of the branches and their stages. In the study conducted by Gokulu (2017), it is seen that most of the candidate teachers have positive views on the candidate teacher training process in response to the answers given by the candidate teachers to the questionnaires. This data includes the candidate teachers who have been trained in different cities. But they do not support each other in some ways. It is believed that this is the result of research methods, sample groups, and practices in schools.

Regarding the operation of the school's practice, a directive was issued by the Ministry of Education, and none of the prospective teachers clearly stated the program even though it was programmed. It is also possible to say that different applications are applied in the schools regarding what the teacher candidates share. The fact that the works related to this subject reflect different results in literature also supports this opinion.

Even though Aksu, et al (2015) and Solak (1999) have made a suggestion as "the teacher candidate should attend the course under the supervision of a guidance teacher", the majority of the teacher candidates within this research see such training as unnecessary. Because they think that it is similar to the education and practice they have had in their undergraduate education, they are given trivial chores and they cannot feel like teachers with the influence of the people around them. Contrary to this research, in the study of Ute (1990), it is generally concluded that after candidate education, candidate teachers gain the independent working ability and that school principals and guidance teachers have a positive attitude towards candidate teachers which means an effective upbringing is achieved. Similarly, in the Evertson and Smithey (2000) study, it is shown that teachers participating in the candidate training program provided by the mentors gain the ability to organize education and classroom routines more effectively. It was also observed that teachers had a positive relationship with their students and that they received more participation. It is possible to find other researches in literature that show that these programs help professional development of first-year teachers in the first year of work (as cited in Ergenekon, 2009; Feiman-Nemser and Parker, 1990; Odell and Ferraro, 1992; Schaffer, Strigfield and Wolfe, 1992). However, research conducted by Ekinci (2010) has shown that school principals are not sufficient to fulfil their role as mentors in the job training process. While some researchers in literature support the data of this research, some of them do not. This can be explained by factors such as human, time, application of candidacy education.

Candidate teachers have often stated that they are not aware of the difference between the school application courses they have taken during their undergraduate studies and this training, or that the responsibility of the candidacy training and the length of the course description are excessive. In fact, the responsibility mentioned by some of some of the candidate teachers is the same in both. But how it feels differs with them. The difference in the lecture duration is correct. In the undergraduate study, they attend only one day a week and each consultant teacher deals with six undergraduate students. This is also what the undergraduate study lacks. One class, one counsellor, six students, one day a week reduce the impact of the practice. Yildirim Haciibrahimoglu (2016) conducted a metaphor study for the preschool fourth-year students who wanted to define the guidance teachers as part of the school application course and noted that the most repetitive concept was "inefficient". In the study of Secer, Celikoz and Kayili (2010), the most frequently expressed problems stated by the students during the school application course are the negative attitudes of the guidance teachers towards the teacher candidates, the tendency to enter into extracurricular expectations, to see them as assistants in the schools and not to guide them adequately. This data supports the research.

Article 11, which explains how to set up a mentor teacher in the regulation prepared by MEB for candidate teacher education, emphasized that the mentor should have at least ten years of service. In the second bend, however, it is remarked that if there is no teacher with ten years of service in the city where the candidate is appointed to be raised, those with less than ten years in service duration can be assigned as well. In practice, teacher candidates have already been given the right to receive candidacy training at the desired city. If there are no teacher with ten years of service in the city the teacher candidate applies for, they could be directed to other cities instead. It is necessary to discuss the question "Could the counselling of a teacher who is already in the beginning of his career be adequate?" While the results of many studies show that such practices are beneficial (Gul, Turkmen and Aksel, 2017), the selection and training of consultants influence the effectiveness of these practices. When we look at the answers given by the teacher candidates about the evaluation of their advisors, it seems that there are very few candidates who define it as "sufficient". The grades given by the advisor teachers and administrators to the candidate teachers are very high. This 
situation explains the statements of the candidates "I think they make a fair assessment" regarding their advisor teachers, and as answers to the first question, asking what did you take into consideration when you chose the city of training, their statements such as "the place where my family lives", and "the familiar teachers, administrators". In a quantitative research by Gokulu (2017), almost half (45\%) of advisor teacher do not support candidate teachers in the course planning and evaluation stage and did not fill in the required forms to be completed weekly. This data also supports research findings. The purpose of the practice implemented by MEB is to help the cooperation between the prospective candidate teacher and the consultant teacher to support the professional development of the candidate teacher. This situation is also handled by Liaw in literature (2009).

In a study conducted by Kosterelioglu and Akin Kosterelioglu (2008), it was found that candidate teachers generally perceived themselves as "largely" adequate for the profession. In this study, the majority of the candidate teachers stated that they were not regarded as teachers by the other teachers. For this reason, the process has been very troubling for candidate teachers, lacking the sense of belonging, and causing them to experience a confusion about their roles. However, in the study conducted by Seferoglu (2000), it is stated that the experienced teachers can provide moral support to new teachers, share their problems in a positive environment they create, invite them to their own classes, give them sample lessons and help them adapt to their surroundings. In the research by Tuncbilek and Tunay (2017), it is said that other teachers' expectations about candidacy education are very low, which explains the lack of communication between candidate teachers and other teachers.

A similar situation is observed the candidate teachers' relation to the students. Both the students and the prospective teachers are confused about the relations with the candidate teachers. The lack of the sense of belonging and the feeling of not feeling like a teacher cause the candidate teachers to be exhausted before they start their profession, as they say. Tuncbilek and Tunay (2017) support the data of this research that candidate teachers have the lowest expectancy, according to manager and advisor teacher groups in terms of providing the students with good communication skills.

Finally, a comparison between the concepts of substitute teacher and candidate teacher has been carried out in the research. The research done by an education union revealed that in 2017 the number of substitute teachers was approximately 63.829 (Turk Egitim Sen, 2017). Considering the conditions for becoming a substitute teacher, while the general conditions apply equally in the whole country, priorities for assignment can vary according to Provincial Directorates of National Education. While some National Education Directorates require graduation from an Education Faculty, some may even charge associate degree graduates as substitute teachers. In other words, the Provincial Directorate of National Education may charge one of the associate degree graduates from any area as a substitute teacher. It is a contradiction that such an application is already in place while the teacher candidates who have finished the Faculty of Education and have been entitled to be appointed are not able to attend classes adequately. In another application, while 240 thousand enrolments are given to high school graduate students who will choose Education Faculties, a right of teaching is granted with a personal formation training which can be placed in the undergraduate program by passing the entrance examination to the university. Such contradictory practices reduce the effectiveness of teaching. OECD (2005) report and Heinz (2008) have shown that it has to be given more importance on both candidate teacher education program and teacher selection criterions.

At the end of this research, the following suggestions can be made:

- $\quad$ Serious reforms must be made on teacher training before candidacy education begins.

- Pedagogical Formation, Substitute-Vocational Education, etc. should be abolished. The need for teachers should be met with permanent, appointed teachers.

- Candidacy education should be based on scientific basis. For example, Aksu and his colleagues (2015) have reached the conclusion that peer counselling and clinical supervision provide favorable conditions for candidacy training. Scientific studies like this and such should be carried out, pilot applications should be run and applied to the entire country.

- Candidacy training should not change in six months. The practice should start with long-term plans.

- All selected elements for candidacy training should be prepared and the sub-structure should be completed and implemented. The same practice should be conducted in every school. All workers should be educated about the subject.

- A new candidacy education model can be designed by examining the candidacy education programs abroad.

\section{References}

Aksu, M. B., Aksu, T., Apaydin, C., Kasalak, G. Tan, O., \& Senol, Y. (2015). Promoting practical training process of novice teachers through peer consultation and clinical supervision. Educational Administration: Theory and Practice, 21(2), 131-160. DOI: 10.14527/kuey.2015.006

Altunya, N. (1990). Koy Enstitulerinin tarihcesi: Kurulusunun 50. yilinda Koy Enstituleri [History of Village Institutes: Village Institutes in the 50th year of foundation]. Ankara: Egit-Der Yayinlari 2. 
Arkin, G. (1945). Ilk okul ogretmenine temel kitap [Basic book to primary school teacher]. Istanbul: Turkiye Yayincilik.

Balci, A. (2000). Orgutsel sosyallesme: kuram, strateji ve taktikler [Organizational socialization: theory, strategy and tactics]. Ankara: PegemA Yayincilik

Bas, T. (2001). Anket [Questionnaire]. Ankara: Seckin Yayinlari.

Buyukozturk, S. (2005). Anket gelistirme [Questionnaire development]. The Journal of Turkish Educational Sciences, $3(2), 133-151$.

Duran, E., Sezgin F., \& Coban O. (2011). Examining candidate classroom teachers' compliance and socialization process. Dumlupinar University Journal of Social Sciences, 31, 465-478

Ekinci, A. (2010). Roles of headmasters on the job-training of the pre-service teachers. Dicle University Journal of Ziya Gokalp Faculty of Education, 15, 63-77

Ergenekon, Y. (2009). The support services being provided to the special education teachers in their first year. Ankara University Journal of Faculty of Educational Sciences, 42(1), 215-239

Evertson, C. M., \& Smithey, W. M. (2000). Mentoring effects on proteges classroom practice: An experimental field study. The Journal of Educational Research, 93(5), 294-305.

Feiman-Nemser, S., \& Parker, M. B. (1990). Making subject matter part of the conversation of learning to teach. Journal of Teacher Education, 41(3), 32-43.

Gokulu, A. (2017). Prospective teachers' views about the prospective teacher training process in Turkey. International Journal of Social Sciences and Education Research, 3(1), 111-123.

Gul, I., Turkmen, F., \& Aksel, N. (2017). Evaluation of the candidate teacher training course according to candidate teacher opinions. Hitit University Journal of Social Sciences Institute, 10(1), 365-388

Heinz, M. (2008). The composition of applicants and entrants to teacher education programmes in Ireland: trends and patterns. Irish Educational Studies, 27(3): 223-240. doi: 10.1080/03323310802242153

Hoy, W.K., \& Woolfolk, A. E. (1990). Socialization of student teachers. American Educational Research Journal, 27(2), 279-300.

Ingersoll, R., \& Strong, M. (2011). The impact of induction and mentoring programs for beginning teachers: A critical review of the research. Review of Education Research, 81(2), 201-233

Kane, R.G. (2008). Evaluation of the new teacher induction program (NTIP) year one results executive summary. Retrieved from http://www.edu.gov.on.ca/eng/policyfunding/memos/june2008/ExecutiveNTIP.pdf

Korkmaz, I., Saban, A., \& Akbasli, S. (2004). Professional challenges encountered by beginning classroom teachers. Educational Administration in Theory \& Practice, 38, 226-277.

Kozikoglu I., \& Cokuk, K. (2017). Beginning teachers' completion of induction program in a different province: opinions and experiences of beginning teachers. Ankara University, Journal of Faculty of Educational Sciences, 50(2), 167200.

Kosterelioglu I., \& Akin Kosterelioglu, M. (2008). Stajyer ogretmenlerin mesleki yeterliklerini kazanma duzeylerine iliskin algilari. Sakarya Univesity Journal of Arts and Science, II, 257-275

Kumbetoglu, B. (2005). Sosyolojide ve Antropolojide Niteliksel Yontem ve Arastirma [Qualitative Method and Research in Sociology and Anthropology]. Istanbul: Baglam Yayincilik.

Kurum Yapicioglu, D., Ozturk T., \& Yetim N. (2016). Sen stajyer ogretmen misin? Aday ogretmen misin? Ogretmen misin? Aday ogretmenlik uygulamasi uzerine bir inceleme. 4th International Conference on Curriculum and Instruction, Antalya, Turkey

Lay, C. D., Pinnegar, S., Reed, M., Wheeler, E.Y., \& Wilkes, C. (2005). The positioning of preservice teacher candidates entering teacher education. In Jere Brophy, Stefinee Pinnegar (Ed.) Learning from research on teaching: Perspective, methodology and representation. Advances in Research on Teaching, 11, 235-252.

Liaw, E. C. (2009). Teacher efficacy of pre-service teachers in Taiwan: The influence of classroom teaching and group discussions. Teaching and Teacher Education, 25(1), 176-180.

Lynch, R., McCormack, O., \& Hennessy, J. (2017). Exploring the position of curriculum studies across the continuum of teacher education in Ireland. Irish Educational Studies. doi: 10.1080/03323315.2017.1350595

Mingo, A. L. W. (2012). Evaluating the impact of the beginning teacher induction program on the retention rate of beginning teachers (Unpublished Doctorate Dissertation). Gardner-Webb University, NC, USA. 
Odell, S. J., \& Ferraro, D. P. (1992). Teacher mentoring and teacher retention. Journal of Teacher Education, 43(3), 200204.

Oral S., \& Demir, F. (2016). Aday ogretmenlerin aday ogretmen yetistirme surecine iliskin gorusleri. 4. International Conference on Curriculum and Instruction, Antalya, Turkey

Organization for Economic Co-operation and Development (OECD). (2005). Teachers matter: Attracting, developing and retaining effective teachers. Paris: OECD. Retrieved at 26.10.2017 from https://www.oecd.org/edu/school/34990905.pdf

Sarica R., \& Turan- Ozpolat E. (2016). Aday ogretmen yetistirme surecine iliskin aday ogretmen gorusleri (GaziantepOsmaniye illeri ornegi) 4. International Conference on Curriculum and Instruction, Antalya, Turkey

Schaffer, E., Stringfield, S., \& Wolfe, D. (1992). An innovative beginning teacher induction program: A two-year analysis of classroom interactions. Journal of Teacher Education, 43(3), 181-192.

Secer, Z., Celikoz, N., \& Kayili, G. (2010). Problems in school practices in department of pre-school teaching and solution offers. YYU Journal of Education Faculty, 7(1): 128-152.

Seferoglu, S. S. (2000). The role of experienced teachers in teacher development. Education and Science, 25(118), 9-17.

Solak, I. (1999). Aday ogretmenlerin yetistirilmesine iliskin yonetmelikte ongorulen uygulamali egitimin degerlendirilmesi (Unpublished master's thesis). Inonu University Institute of Social Sciences, Malatya, Turkey.

Thompson, M., Paek, P., Goe, L., \& Ponte, E. (2005). The impact of new teacher induction on teacher practices and student learning. In Annual Meeting of the American Educational Research Association. Montreal, Canada: Educational Testing Service. Retrieved from http://www. ets. org/research/dload/AERA_2005_Thompson.pdf.

Tuncbilek M., \& Tunay T. (2017). Percieve of relevant parties to canditate teacher training process of ministry of national education in Turkey. Electronic Journal of Social Sciences, 16(61), 412-427.

Turk Egitim-Sen. (2017). Ucretli ogretmen sayisi 81 ilde 63 bin 829 [Number of paid teachers in 81 cities 63829]. Retrieved at 14.06.2017 from https://www.turkegitimsen.org.tr/icerik_goster.php?Id=11440

Ulubey, O. (2018). Evaluation of novice teacher training program. Hacettepe University Journal of Education, 33(2), 480502.

Ute, I. H. (1990). Application of candidacy in teaching and role of the manager (Unpublished doctoral thesis). Firat University Institute of Social Sciences. Elazig.

Yildirim Haciibrahimoglu, B. (2016). Prospective early childhood teachers' mental images about the concepts of "supervising teacher". Turkish Online Journal of Qualitative Inquiry (TOJQI), 7(3), 245-278.

Yildirim, A., \& Simsek, H. (2005). Sosyal Bilimlerde Nitel Arastirma Yontemleri [Qualitative research methods in the social sciences]. Ankara: Seckin Yayinlari. 